\title{
Government (Industrial) Policies for Competitiveness in a Global Economy
}

\author{
David G. Tarr
}

What reforms, policies or instruments should be employed to best achieve a reoriented restructured globally competitive industrial structure? We provide guidance on these questions based on general surveys of the experience of developing countries with industrial restructuring (see Leiberman, 1990; Atiyas, Dutz, Frischtak and Hadjimichael, 1992; Westphal, 1990; Krugman, 1989 and 1992).

The general principle is that it is crucial for the government to provide a stable macroeconomic environment conducive to business development with a clear, transparent and neutral regulatory environment and neutral incentives to all firms and industries. Clear, transparent and neutral incentives (those which do not distinguish by sector or firm) are crucial so that entrepreneurial innovation is rewarded more highly than rent-seeking activities. The economy must provide its most talented members with the incentive to engage in entrepreneurial activities such as starting or expanding firms, developing new products and lowering costs. If the economy provides extensive subsidies or tax exemptions to industries or firms, or presents a difficult regulatory framework within which to do business, corruption will be encouraged and, crucially, talented people will find it more profitable to engage in the socially wasteful activity of lobbying the government for subsidies, protection, tax or regulatory relief (see Murphy, Shleifer and Vishny,1991). This socially wasteful lobbying is especially harmful because it attracts scarce entrepreneurial talent that would otherwise be devoted to helping the economy grow.

Targeting particular industries for special assistance involves a number of risks that are potentially very costly. First, there is the risk that the wrong industries will be identified. The market is a more reliable indicator of the industries that have comparative advantage than any economic model or theory. Over time this is particularly true, as comparative advantage changes with technological development. Moreover, targeting industries as "winners" will generate rentseeking where industries will spend resources to obtain government subsidies rather than attempting to compete more effectively on the market. Governments often find it difficult to resist these pressures. And assistance that is designed to be temporary may become permanent. Thus, experience in most countries has shown that a government policy of attempting to "pick winners" is highly counterproductive. Endorsement of a more general approach to industry development--with little differentiation in the level of assistance among industries-- thus emanates from a wider skepticism about the practical merits of targeting of any kind, see Westphal (1990) and Krugman (1989, 1992).

As a positive policy agenda for establishing industry competitiveness, there is much for the government to do:

\section{$1 \quad$ Sound Macroeconomic Policies}

This includes avoiding overvalued exchange rates, which discourage exports and make import competing sectors vulnerable. Fiscal deficits should be avoided in part because they crowd out private investment, and because they lead to inflation that makes price signals less transparent. 


\section{Provide a neutral, transparent regulatory regime that is neither pervasive nor costly}

Regulatory, tax and licensing regimes that are pervasive, frequently changed and not transparent should be avoided since they encourage rent-seeking for regulatory relief.

\section{Provide Sound Competition Policies}

This includes first and foremost an open trade regime such that firms produce according to comparative advantage and are forced to compete. Moreover, export growth has been crucial to all recent development miracles, and import protection imposes an implicit tax on exporters. Constraints on foreign investment, including restraints on repatriation of profits and royalties, as well as inadequate protection of intellectual property, limit access to state of the art production technology and to marketing networks. Barriers to entry and exit (including licensing of capacity expansion and limits on firm size), as well as discretionary subsidies, prevent industrial development and constrain the ability to respond to new competition. Complex licensing requirements often exclude small firms for whom the costs of dealing with the bureaucracy are excessive. Protection of state-owned monopolies, including special pricing arrangements, subsidies and credits, reduces the incentive to the state-owned enterprise to restructure and inhibits competition from new more efficient competitors (who are often private and often an effective means of privatizing the industry). Price controls prevent the transmission of market signals to firms, and should be avoided.

\section{Develop Sound Labor Market Policies}

Policies which facilitate labor mobility are crucial in effective restructuring. Estimates have shown that labor adjustment costs are often larger where labor adjustment is restricted (Leiberman, p. 7). Therefore layoffs should not be restricted or penalized by law. Strong unions sometimes act as an important barrier to effective labor mobility. Retraining programs may play a useful role in facilitating labor mobility, but need to be demand driven.

\section{Adequate Infrastructure}

Inadequate or inefficient infrastructure in ports, roads, telecommunications, water and electricity can hinder industrial competitiveness. At the same time, costly public projects in these areas will increase the fiscal burden, crowd out private investment and similarly hinder industrial competitiveness. Infrastructure projects should therefore target bottleneck areas for efficiency and attempt innovative financing and participation solutions that involve the private sector.

Technical assistance in the form of information and marketing, technology transfer and training programs may also be useful. These programs would include those that help firms develop an effective export marketing strategy, that focus on adopting foreign technology to local conditions and that are designed to develop a flexible labor force. Industry associations and efficient banks are likely to be the best agents for identifying and arranging appropriate technical assistance.

\section{References}


Atiyas, Izak; Dutz, Mark; and Frischtak, Claudio; with Bita Hadjimichael, Fundamental Issues and Policy Approaches in Industrial Restructuring, Industry Series Paper No. 56, The World Bank, April 1992.

Krugman, P. A. (1992), "Does the New Trade Theory Require a New Trade Policy," World Economy, Vol. 15, pp. 423-442.

(1989), “Is Free Trade Passe,” Journal of Economic Perspetives, Vol. 1, pp. 131-144.

Leiberman, Ira, Industrial Restructuring: Policy and Practice, Policy and Research Series No. 9, Washington D.C.: The World Bank, 1990.

Murphy, Kevin; Shleifer, Andrei; and Vishny, Robert, "The Allocation of Talent: Implications for Growth", Quarterly Journal of Economics, May 1991.

Westphal, L.E. (1990), "Industrial Policy in an Export-propelled Economy: Lessons from South Korea's Experience," Journal of Economic Perspectives, Vol. 4, pp. 41-60. 